\title{
直線被害則による鋼部材片の疲れ寿命予測 \\ STUDY ON THE ESTIMATION OF FATIGUE LIFE OF STEEL MEMBERS BY LINEAR DAMAGE RULE
}

\author{
張 東 一*.三 木 丰林・西 村 俊 夫*** \\ By Dong Il CHANG Chitoshi MIKI and Toshio NISHIMURA
}

\section{1. 序説}

\section{（1）鋼構造物の疲れ寿命予測の必要性}

鋼橋など変動外力を受ける鋼構造物には, 使用年数の 増加につれ構造の各部に疲れに起因する諸変状が生じて くるおそれがある. 特に, 近年は交通量の飛躍的増加や 設計応力と作用応力の接近あるいは高強度鋼を使用した 溶接構造の採用など, 土木構造物にとっては疲れ破壊に 対し厳しい条件になりつつあり, 事実, 鋼構造物の疲れ 破壞あるいは疲れきれつ進展後, 脆性破壊を生じた事例 がわが国および諸外国で折々に報告されている

数十年間にわたり使用される鋼橋に, また, 疲れ現象 にまだ知識が不十分であった時代に建設されたものに， 疲れ変状が発生することはある程度やむを得ないが，こ れら構造物の安全を確保するためには検査を適切に実施 して, 変状を早期に発見し, その対策を速やかに構ずる ことが必要である.しかし, 多数の鋼構造物に対し, し かも各構造物は, 多種多様な構造要素から構成され, ま た, 常時車両が走行しているなど, この点検作業はかな り困難な場合が多い。したがって, 検査を合理的に実施 するためには変状発生のおそれがある箇所および時期に 重点的に作業を行う必要がある.このため, 各種構造部 分に対し変状発生の時期を予測することが望まれるが, これら橋梁は過去長期にわたり使用し続けられ，その 間, 載荷条件は時代とともに変遷し, また, 構造の各部 は次第に老朽し, これらを考虑して疲れ寿命の予測を行 うことは困難な問題である.

橋梁の維持管理などの必要から, わが国鋼鉄道橋で採

\footnotetext{
* 正会員 工碩 大韓民国 漢陽大学校副教授 工科大 学土木工学科

** 正会員 工修 東京工業大学助手 工学部土木工学科

*** 正会員 工博 東京工業大学教授 工学部土木工学科
}

用されている疲れ被害の評価法は3),4), 定応力下での疲 れ破断寿命に対する標準的応力繰返し数線図 ( $S-N$ 線) を定め, この $S-N$ 線を使用し, 過去ならびに現在の走 行荷重による慣行計算応力と列車回数に基ゔき修正 Miner 則あるいは Corten-Dolan の方法を適用して疲 れ被害（基準荷重に対する換算繰返し数）を算定し，基 準荷重による計算応力值との関係でその安全性を判定し ようとするものである.この方法は鋼橋の疲れ被害を推 定する一つの有力な試みであるが，なお若干の問題点を 含み，そのおもなものは，i）疲れ破断寿命を基準として 疲れ被害則を 適用していること. ii）重連運転および電 車専用区間を除き慣行計算応力が 1 列車 1 回作用すると していることである.i）については近年の疲れ寿命に 関する研究より破断寿命と被害則との関係を見直す必要 があり，ii）については橋梁に作用する実際応力は慣行 計算值を一般にかなり下回り, 特に動的応力は複雑な性 状を示し, また, 変動応力が疲れ被害に及ぼす影響が無 視されている. これらより, 疲れ変状の発生時期には相 当の予測誤差が生ずるおそれがあり, 鋼構造物の安全性 確保のうえから, より適切な寿命予測法の確立が望まれ るところである.

\section{（2）疲れ寿命予測に関する従来の研究}

応力を繰返しらける部材の寿命予測のための被害則と しては, A. Palmgren, B.F. Langer, 西原 ${ }^{5)}$, Miner $^{6)} ら$ によって提唱された值線被害則が，その取り扱いが容易 で実用的なことによりよく知られている.これは疲れ破 壊は式（1）のごとく累積繰返し数比が 1 になる場合に 生ずるとするものである.

$$
\sum n_{i} / N_{i}=1
$$

ここに, $N_{i}$ は疲れ限度以上の応力（過大応力）に対す る疲れ寿命, $n_{i}$ はその応力での絽返し数である.この 被害則の成否を検討する多数の実験が行われた結果, こ の仮説は必ずしも成立しないことが報告され7),8), 各研 
究者によって種々の修正式が提案されてきた.このらち 重要なのは, 疲れ限度以下の応力（過小応力）が疲れ寿 命に及ぼす影響の取り扱いで，過大応力下で発生した疲 れきれつは過小応力によっても進展するから, 寿命予測 にこのことを反映する必要がある. Corten-Dolan ${ }^{9)}$ は定 応力に対する $S-N$ 線を疲れ限度以下まで伸ばすととも に，その勾配を急にして適用することに帰する方法を発 表し, 勾配修正について論議を行っている ${ }^{10)} . S-N$ 線 を単に疲れ限度以下まで延長して適用するいわゆる修正 Miner 則 ${ }^{11}$ も使用され，また，延長部分のみ勾配を急 にする川田らの提案 ${ }^{12)}$ もるる.

以上に述べた諸研究ではきれつの発生寿命と進展寿命 を必ずしも明確に区別していないが, 疲れ寿命の予測精 度を向上するため両者をわけて取り扱うことが考えら れ，Grover ${ }^{13)}$ はそれぞれの寿命に対して直線被害則を 適用し, Manson ${ }^{14)}$ らは Double Linear 則を適用しここ れより求めた有効きれつ発生寿命に対して $S-N$ 線を作 成し寿命推定を行っている. 中沢ら ${ }^{15)}$ は S $25 \mathrm{C}$ 砂時計 型試験片の二段二重, 三段三重回転曲げ実験から, きれ つ発生寿命は直線被害則による予測值にほぼ一致すると の結果を示し，また，青木・国尾・中村 ${ }^{16), 17)}$ \& S 15 C, S 40 C 切欠き試験片の多段多重および応力振幅を正 弦波状に変化させる回転曲げ実験より, 西谷 ${ }^{18)}$ ら浅い 切欠きをもつ S $20 \mathrm{C}$ 材の二段二重回転曲げ実験から同 様の結論を導いている.

一方, 疲れ被害則を適用して寿命計算を行う場合, 作 用応力の頻度解析法として伊藤 ${ }^{19}$ は振幅範囲計数法によ るのが適当であるとし，また，Corten ${ }^{10)}$, Hofmeister $^{20)}$ の平均応力の影響を考虑して頻度分布を定めた研究もあ る.また,応力頻度曲線に基づくプログラム実験により疲 れ寿命を求める研究も盛んに行われているが, 河本 ${ }^{21)}$ は応力の頻度解析法, 1 応力ブロックの繰返し数その他 各種因子が実験結果に影響するとし, 砂本ら ${ }^{22)}$ はこれら 影響の補正方法について述へている.また Naumann ${ }^{23)}$,

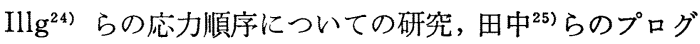
ラム実験による寿命推定の是非に関する研究など各種試 験条件下の成果が報告されているが，これらの場合の疲 れ寿命はいずれもきれつ発生を対象としたものではない．

\section{（3）本研究の範囲}

鋼橋などの鋼部材では軸方向またはこれに準ずる応力 が支配的で, かつ構造物の自重などに よる死荷重応力が最小応力として常時 作用し，構造物上を車両が走行すれば 活荷重応力などが加算されて最大応力 に達する.また，鋼部材およびその連 結部は断面構成上各種の切欠きをもつ
構造となっている.このような応力, 構造条件に対し近 年の疲れ寿命に関する研究は機械構造用炭素鋼の主とし て回転曲げ応力状態について行われており, 使用試験片 も円形断面の砂時計型あるいは環状切欠き系のものが多 い. 本研究ではこれらのことがらに留意し, 鋼部材に多 用される 40 キロ級構造用鋼材で製作した平滑試験片と 切欠き試験片を選定し, 前者には回転曲げ応力を, 後者 には最小応力をもつ軸応力を採用し, 次の各項目につき 主として実験的に究明を進めた。i）定応力が作用する 場合の疲れきれつ発生性状ならびにきれつ発生, 破断寿 命に対する $S-N$ 線. ii）応力履歴の影響が最も顕著に あらわれると考えられる二段二重応力が作用する場合の 寿命予測. iii) 変動応力下の寿命予測と寿命予測精度を 補らためのプログラム応力実験.

これらについての検討より鋼部材の疲れ寿命予測は寿 命基準を破断よりきれつ発生にとったほうが一般に精度 のよくなることを明らかにしたものである.

\section{2. 疲れ寿命実験の方法}

\section{（1）使用試験片と試験装置}

回転曲げ応力による疲れ実験には, 図一1（a）に示す 円形断面の平滑試験片を使用した。本試験片は JIS 規 格 ${ }^{26}$ による回転曲げ疲れ試験片 ( 1 号) の平行部 $(\phi 12$ $\mathrm{mm}$ ) 長さを $20 \mathrm{~mm}$ に短縮しているが，これはきれつ 発生に対する監視範囲をせばめるためである、試験片は

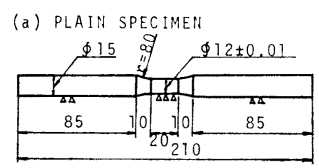

(b) CIRCULAR NOTCHED SPECIMEN

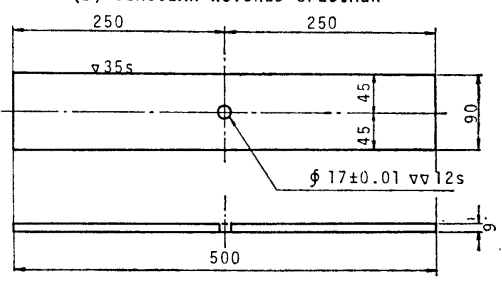

unit:mm

図一1疲れ試験片の形状と寸法

\section{表 -1 使用鋼材の化学成分と機械的性質}

\begin{tabular}{|c|c|c|c|c|c|c|c|c|c|}
\hline \multirow[b]{2}{*}{ 試験片 } & \multirow[b]{2}{*}{ 材質規格 } & \multicolumn{5}{|c|}{ 化 学 成 分 $(\%)$} & \multicolumn{3}{|c|}{ 機械的 性 質 } \\
\hline & & C & $\mathrm{Si}$ & $\mathrm{Mn}$ & $\mathbf{P}$ & $\mathrm{S}$ & $\begin{array}{l}\text { 降 伏点 } \\
\left(\mathrm{kg} / \mathrm{mm}^{2}\right)\end{array}$ & $\begin{array}{c}\text { 引張 強 } \\
\left(\mathrm{kg} / \mathrm{mm}^{2}\right)\end{array}$ & 伸 び \\
\hline 平 滑 & SS 41 & 0.16 & 0.22 & 0.49 & 0.011 & 0.022 & 30 & 45 & 33 \\
\hline 切欠き & SM $41 \mathrm{~A}$ & 0.19 & 0.02 & 0.73 & 0.011 & 0.016 & $30 \sim 32$ & 42 & 32 \\
\hline
\end{tabular}


表一1 亿示す化学成分と機械的性質をもつ $\phi 19 \mathrm{~mm}$ 圧 延丸棒鋼から製作し，また材料の圧延時残留応力を除去 し，かつ内外層を均質化するため焼なまし処理を行った。 すなわち, 試験片各部の直径を所定寸法に対し $+1 \mathrm{~mm}$ で一次加工し，これを電気炉中で $600^{\circ} \mathrm{C}$ に 1 時間保持

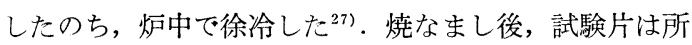
定寸法に切削ならびに研削加工を行ったが，機械加工に よる残留応力の再発を軽減するため 1 回削り代を極力減 らし入念に仕上げた。ささら平行部は研摩し, 特に最終 仕上げは軸方向に研摩してきれつ発見を容易にするよう にした.

軸応力による疲れ実験には, 図一1 (b) に示す平板型 円孔切欠き試験片を使用した. 切欠き試験片に各種型式 のものを使用することは望ましいが，疲れに対する性状 はある程度準ずるものと考え，また，基礎的実験でもあ るので切欠き材を代表するものとして，リベットあるい はボルト構造に一般的に用いられる上記型式を採用し た. 試験片は 表一1 に示す厚さ $9 \mathrm{~mm}$ の圧延鋼板から 製作した. 試験片中の残留応力がきれつ発生にある程度 影響することが考えられたが，応力集中の大きい切欠き 材でもあり，鋼部材の実情にあわすこととして，本試験 片については焼なまし处理を行わなかった，試験片表面 の黒皮は微小きれつの発見に便なるよう, また, 黒皮剝
の存するところである. 応力繰返しに伴い生ずるすべり 帯中の微視的ボイドは, 成長結合し, やがて微小きれつ となり,これが伝播扡大してゆくのが疲れ損傷の過程で あるが,結晶粒を貫通するすべり線発生時 ${ }^{15)}$, きれつ深さ $0 \mathrm{~mm}$ 時 ${ }^{16), 17)}$, 表面きれつ長さ $0.1 \mathrm{~mm}$ 時 ${ }^{18)}$ など, 研 究者によりいろいろの取り方が示されている. 本研究で は巨視的きれつが試験片表面にあらわれるのを極力早期 にとらえることとし, かつ, きれつの進展状態を測定し て, これより所定寸法のきれつ発生寿命を推定すること とした. なお, 微小きれつの測定には, 切久き試験片に 対し顕微鏡による試験片表面の観測 ${ }^{18)}$, 所定回数繰返し 後軸方向に試験片を切断し16),29)，あるいはきれつを加 熱着色した後その疲れ破面よりきれつ深さを測定する ${ }^{17)}$ などいろいろ試みられているが，本実験では従来あまり 試みられていない平滑試験片の微小きれつ測定も対象と するため, 表面レプリカ法を採用することにした ${ }^{30)}$. す なわち, 試験片のうける繰返し数がきれつ発生予想回数 に近づいた時, 寿命の長短に応じあらかじめ定めた繰返 し数ごとに試験機の稼働を停止し, 試験片に静荷重をか けたままの状態できれつ発生が予想される部分からレプ リカを採取し，これを顕微鏡で拡大観察しきれつの有無 を点検した.このようにして微小きれつの発見に努める とともに, きれつ発生をみたものは以後の進展状態を前
離などによる実験結果のばらつき を防ぐため, 切欠き部付近の黒皮 を研摩紙で除去した。

定応力振幅, 二段二重およびプ ログラム応力による回転曲げ実験 には小野式回転曲げ疲れ試験機 (3000 回/分) を使用し，作用応 力の切換えは試験機の運転中に荷 重用重錘を増減させることにより 行った. また，(3)，兵）で述べる 方形および三角二次波をもつ回転 曲げ応力による実験には, 本試験 機の重錘載荷部にサーボ機構で駆 動される変動荷重負荷装置 ${ }^{28)}$ を取 り付けたものを使用した．定応力 および二段二重応力による軸引張 実験には, 電気油圧式万能型疲れ 試験機（動的容量 $\pm 50 t$ ，荷重制 御方式）を使用した。

\section{（2）疲れきれつの観測}

試験片のきれつ発生に着目して 疲れ寿命を考える場合, どの程度 のきれつを基準とすべきかは議論

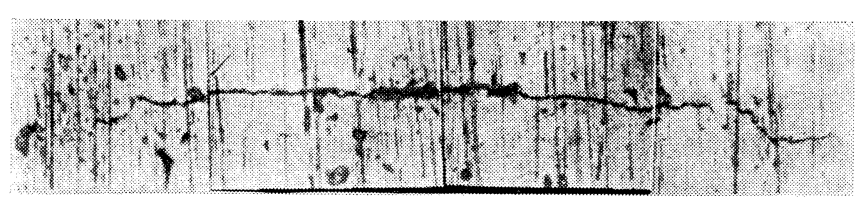

（a）繰返し数 $825 \times 10^{3}$ 回で長さ $0.8 \mathrm{~mm}$ のきれつが表面に発生

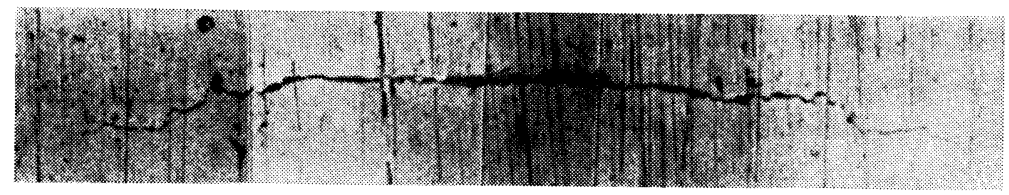

(b) さらに $5 \times 10^{3}$ 回後にこのきれつは長さ $1.0 \mathrm{~mm}$ に成長した (二段二重回転曲げ応力, $S_{1}=27.1 \mathrm{~kg} / \mathrm{mm}^{2}, n_{1}=68 \times 10^{3}, S_{2}=24.7 \mathrm{~kg} / \mathrm{mm}^{2}$ )

写真-1 平滑試験片の疲れきれつ

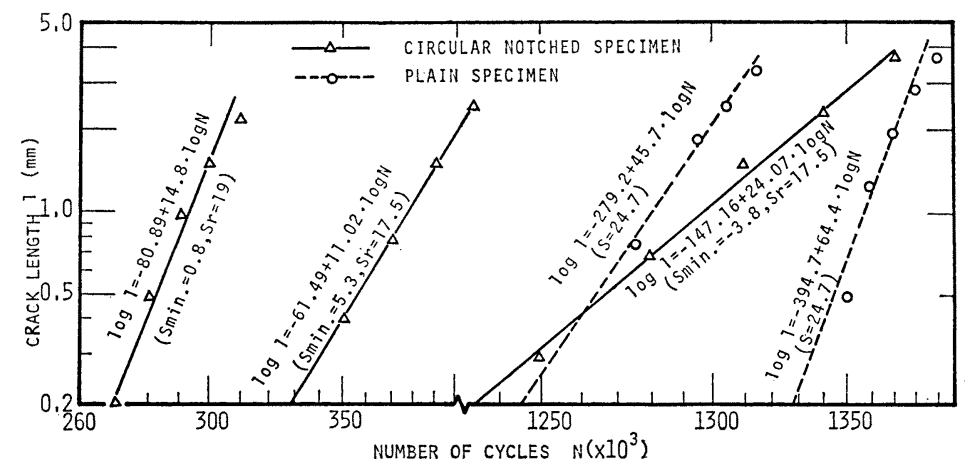

図一2 試験片表面のきれつ長と繰返し数との関係 
と同じ間隔で引続き測定した.

切欠き試験片では最初のきれつ発生が円孔中心を含み 軸と直角断面付近の孔壁かつ板厚中間部に局限されるた め上述の方法で目的が達成されたが，平滑試験片ではき れつ発生予想部分がかなり広範囲にわたるため, 最初の きれつ発見はルーペ (8 倍) による試験片表面の入念な 点検を併用せざるをえなかった. しかし，この方法でも 作業の習熟に伴い, きれつ長 $0.5 \mathrm{~mm}$ 程度のものの発 見は可能であった. 写真一1 はこのレプリカ法により転 写されたきれつの顕微鏡写真の一例である.

かくして測定された疲れきれつは切欠き試験片で一般 に長さ $0.5 \sim 1.0 \mathrm{~mm}$ 前後以上のもので, 長さ $0.2 \sim 0.3$ $\mathrm{mm}$ のきれつ測定は比較的低応力のもので成功した. こ れは低応力時のきれつは微細な反面, 進展速度が遅いの に助けられている.いま, $0.2 \sim 0.3 \mathrm{~mm}$ のきれつ長まで 測定しえたものについて, 試験片表面のきれつ長 $l$ と繰 返し数 $N$ を両対数でプロットすると両者の関係 は図一2 のごとく, きれつ長 $4 \mathrm{~mm}$ 程度までは 線形とみなしても誤差はそれほど生じないことが 確かめられた.また, 同図には平滑試験片について の $l$ と $N$ との関係もあわせ示した. ‘お, $\mathrm{Liu}^{31)}$ はアルミ合金板についての実験結果から $l$ のる 範囲で $\log l$ と $N$ が直線関係になると述べてい るが, 両者の関係は試験片や作用応力の性質など にも影響されるものと考えられる。

本研究におけるきれつ発生寿命の検討には各実 験から求めた $l, N$ の関係を式 (2) で回帰解析 し, 係数 $\alpha, \beta$ を最小二乗法により決定し, それよ りその前後の実測值が得られている $l=0.5 \mathrm{~mm}$ に対応する寿命を算出しておもに使用した.

$$
l=e^{\alpha} N^{\beta}
$$

また，極力微小きれつを取り上げる必要があるも のと考え, $l=0.2 \mathrm{~mm}$ 時の寿命も求めたが, この 值はほとんど実測されておらず，また，微小きれ つの進展過程が単純に式 (2) であらわせないこ と ${ }^{17)}$ も考えられるので参考值として考慮すること とした.

\section{（3）各実験の趣旨と設定応力}

\section{a）定応力疲れ実験}

本実験では定応力振幅回転曲げ応力および最小 応力をもつ定応力範囲軸応力が作用する場合の疲 れきれつの発生進展性状を調べ, また，きれつ発 生および破断寿命に対しそれぞれ $S-N$ 線（以下 基本 $S-N$ 線と称する）を設定することを目的と する. 設定応力は回転曲げ応力実験では疲れ限度 以上, 降伏点以下の応力振幅とし, 相隣る二応力
段階の比は 1.02 とした.軸応力実験では部分片振りおよ び部分両振り応力状態とし, 最小态力は純断面での呼び 応力で $5.3,0.8,-3.8,-8.4 \mathrm{~kg} / \mathrm{mm}^{2}$ の 4 種類とし, 応 力範囲は引張側に疲れ限度以上, $16 \sim 28.2 \mathrm{~kg} / \mathrm{mm}^{2}$ とし た. 試験片の形状係数が $2.54^{32)}$ より最大応力が呼び応 力で約 $13 \mathrm{~kg} / \mathrm{mm}^{2}$ をこえると孔壁の一部は降伏するこ とになる. 応力波形は正弦波, 載荷速度は 600 回/分と した.

\section{b）二段二重応力疲れ実験}

従来の直線被害則に関する研究では疲れ破断を基準に その寿命を考えるものが多かったが，きれつ発生以前と 以後とでは試験片の応力性状が異なることに留意し, 本 実験ではａ）で得られた結果を用い直線被害則をきれつ 発生および破断寿命について適用する場合の寿命予測の 是非について検討した. 設定応力は 図-3 (a), (b) に 示すごとく回転曲げ応力実験では $1.12 S_{0}, 1.02 S_{0}\left(S_{0}\right.$

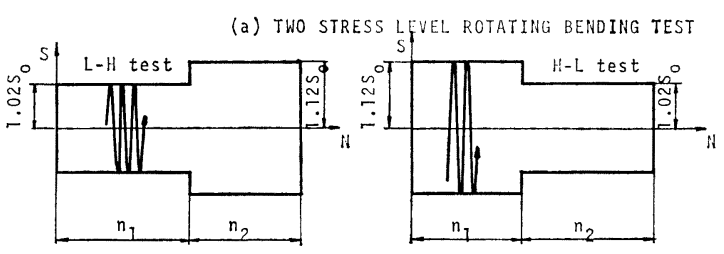

(b) TWO STRESS LEVEL AX.IAL LOADING TEST

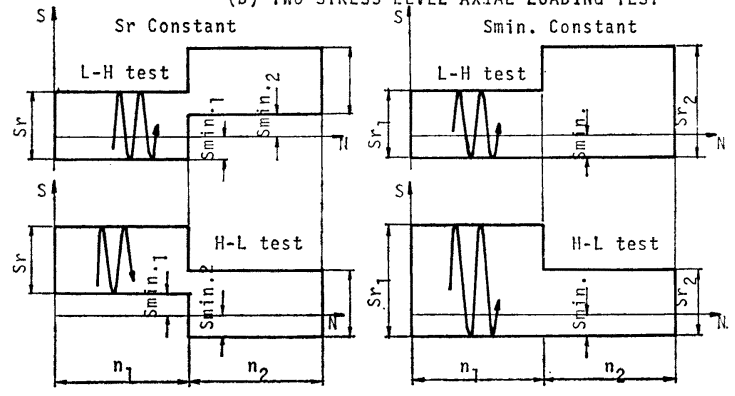

(c) VARIABLE STRESS AMPLITUDE TEST

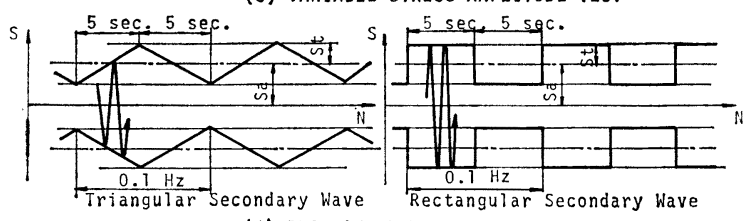

(d) PROGRAM TEST

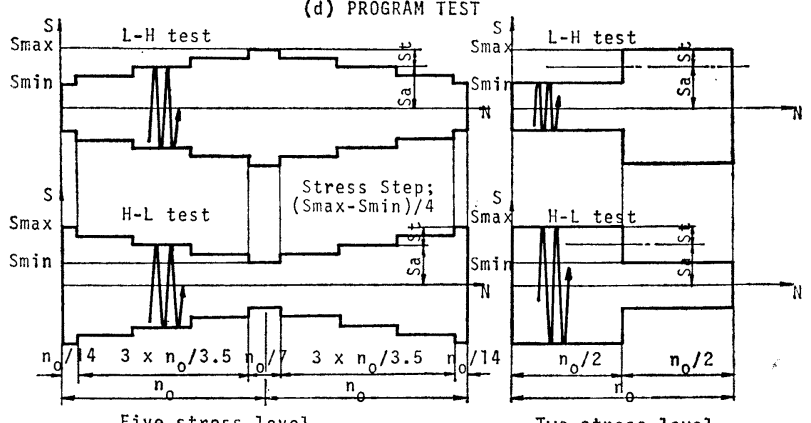

Five stress level

Two stress level

図一3 設定応力パターンの種類 
は疲れ限度で $24.2 \mathrm{~kg} / \mathrm{mm}^{2}$ ) なる高低二応力振幅とし, 応力履歷の影響を求めるため一次応力を低応力とする $\mathrm{L}-\mathrm{H}$ 試験と二次応力を低応力とする $\mathrm{H}-\mathrm{L}$ 試験を実施 した. また, 軸応力実験では一定応力範囲 $S_{r}$ を使用す るものと一定最小応力 $S_{\min }$ を使用するものの 2 種類と し, 両実験とも同じ応力状態の組み合わせで $S_{\min 1}<$ $S_{\min 2}$ あるいは $S_{r 1}<S_{r_{2}}$ なる $\mathrm{L}-\mathrm{H}$ 試験と, $S_{\min 1}>$ $S_{\min 2}$ あるいは $S_{r 1}>S_{r 2}$ なる $\mathrm{H}-\mathrm{L}$ 試験を実施した。 ここに, 一次応力の繰返し数 $n_{1}$ は回転曲げ応力実験の 場合, 当該一次応力に対する $0.5 \mathrm{~mm}$ きれつ発生寿命 の $40 \sim 90 \%$ の範囲に, また, 軸応力実験の場合同じく 25, 50,75\% 付近に適宜選定した.

\section{c）プログラム応力疲れ実験}

二段二重応力が作用する場合の寿命予測は b) により きれつ発生について考えればかなり精度よく行えること が明らかになったが，この成果をさらに複雑な変動応力 （図一3 (c) に示す方形および三角二次波をもつ回転曲 げ応力が重複綝返されるもの）に適用した場合は条件に より誤差が大きくなることが示された．この予測誤差を 圧縮するための一方策として, 本研究ではこの変動応力 と応力頻度分布が同一となるようなプログラム応力を設 定して疲れ実験を行い, 変動応力の寿命を再現すべき応 カブロックの重複回数や疲れ寿命に及ぼす高低初応力の 影響などについて検討した.
図一3 (c) に示す変動応力の二次波の振幅は $S_{t}=1.2$, $2.4 \mathrm{~kg} / \mathrm{mm}^{2}$ の 2 種類とし, 最大応力は材料の降伏点以 下, 最小応力は過大, 過小応力領域とした. また, 二次 波の周波数は予備実験の結果など33),17) から，その大小 が疲れ寿命に及ぼす影響はあまり認められないので 0.1 $\mathrm{Hz}$ の 1 種類のみとした. なお, このような変動応力は 実際鋼部材に作用寸る応力とはかなり異なっているが, 基礎的な検討でもあり, また, プログラム化の容易明快 さなどの点から採用したものである.

プログラム応力は 図-3 (d) に示すごとく, 方形二 次波をもつ回転曲げ応力は二段多重系応力に, 三角二次 波をもつ回転曲げ応力は近似的に五段多重系応力にプロ

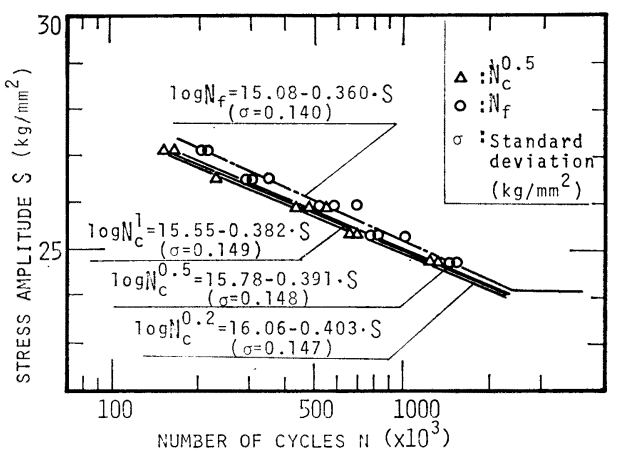

图一-4基本 $S-N_{c}$ 線および $S-N_{f}$ 線 (平滑試験片)

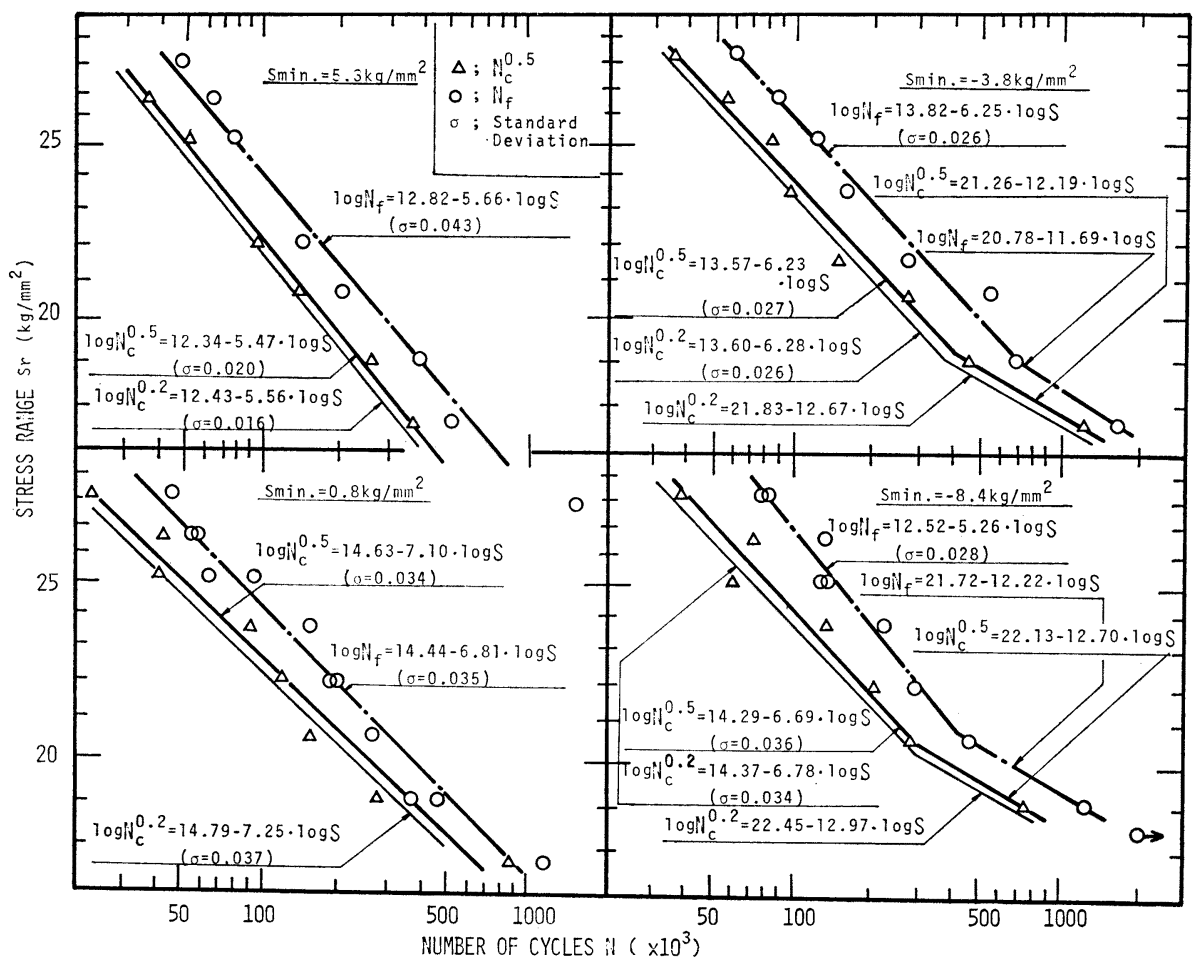

図一5 基本 $S-N_{c}$ 線および $S-N_{f}$ 線（切欠き試験片） 

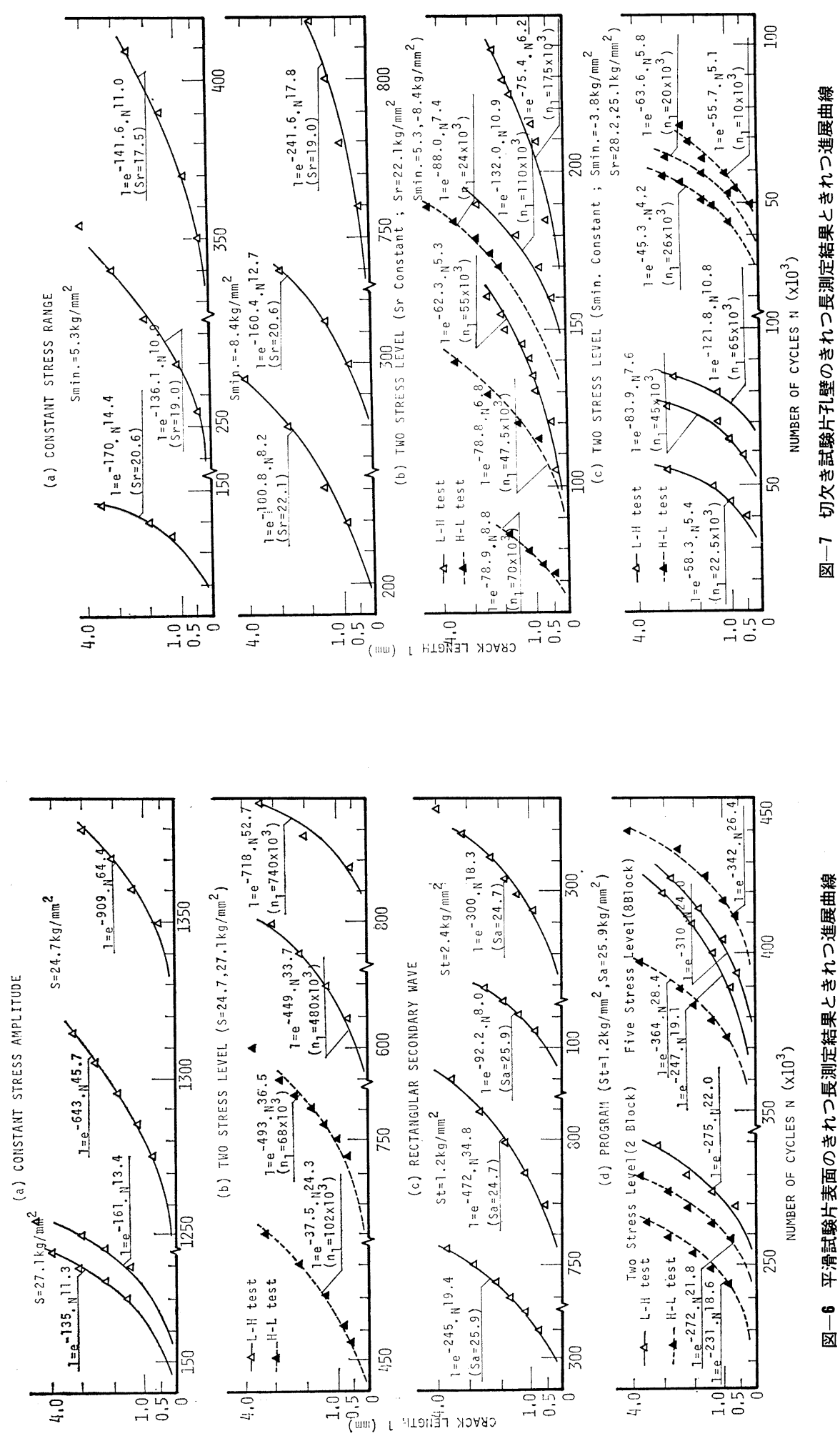
グラム化し, 両プログラム応力とも $S_{a}=25.9 \mathrm{~kg} / \mathrm{mm}^{2}$, $S_{t}=1.2 \mathrm{~kg} / \mathrm{mm}^{2}$ と $S_{a}=24.7 \mathrm{~kg} / \mathrm{mm}^{2}, S_{t}=2.4 \mathrm{~kg} / \mathrm{mm}^{2}$ の 2 種類とした. 1 応力ブロックにおける一次波の繰返 し数 $n_{0}$ は直線被害則で計算した対象変動応力下での $0.5 \mathrm{~mm}$ きれつ発生寿命概算值を $1,2,4$ および 8 で除 したものとした．な㧍，設定ブロック数で試験片が破壊 しなかった場合は引続き同じプログラム応力を繰返すこ ととした。 また，実験は $S_{\mathrm{min}}$ から始まる $\mathrm{L}-\mathrm{H}$ 試験と $S_{\max }$ から始まる $\mathrm{H}-\mathrm{L}$ 試験を行った.

\section{3. 基本 $\boldsymbol{S}-\boldsymbol{N}$ 線の性状}

\section{（1）疲れ寿命の測定と基本 $\boldsymbol{S}-\boldsymbol{N}$ 線の設定}

図一4 は横軸に応力繰返し数 $N$ を対数目盛で, 縦軸 に応力振幅 $S$ を等間隔目盛でとり, 定応力振幅回転曲 げ応力による平滑試験片のきれつ発生寿命 $N_{c}$, 破断寿 命 $N_{f}$ をプロットし，これらに対し最小二乗法により $S-N_{c}$ 線および $S-N_{f}$ 線を求めたものである. また, 図一5 は同様にして求めた定応力範囲軸応力による切欠 き試験片の最小応力 $S_{\mathrm{min}}$ ごとの $S-N$ 線であるが, 縦 軸には純断面あたりの呼び応力で示した応力範囲 $S_{r}$ を 対数目盛でとっている.この場合 $N_{c}$ については 2.(2) より試験片表面のきれつ長が $0.2,0.5$ および $1.0 \mathrm{~mm}$

（軸応力の場合を除く）に到達したときのものとするた め, 図一6 (a), 7 (a) に一例を示すごとく, 各実験ごと のきれつ長測定結果と式 (2) からきれつ進展曲線を定 め,これより $N_{c}^{0.2}, N_{c}^{0.5}$ および $N_{c}^{1}$ を計算している.

図一4で縦軸の $S$ を等間隔目盛にとったのは対数目 盛でとるより計算 $S-N$ 線の分散值が小さく直線性がよ いからである.また, 図一5 において $S_{\min }=-3.8,-$ $8.4 \mathrm{~kg} / \mathrm{mm}^{2}$ の場合の $S-N$ 線は折線形としたが, これ は試験片孔壁に貼付したひずみゲージ（ゲージ長 0.2 $\mathrm{mm}$ ）により把握した 絽返しひずみの性状が， $S_{r}$ の增 大とともに $S-N$ 線の折点付近から弾性的なものから塑 性的なものへ変化し始めることを考慮したものである.

\section{(2) $N_{c}$ と $N_{f}$ の関係}

図一4, 5 中に示した $S-N$ 線式より平滑試験片では $S-N_{c}$ 線は $S-N_{f}$ 線より緩勾配となり, また, $S-N_{c}{ }^{1}$, $S-N_{c}^{0.5}, S-N_{c}{ }^{0.2}$ の順に勾配が緩になっている. また, 切欠き試験片では, $S-N_{c}$ 線は $S-N_{f}$ 線に比しやや緩 勾配か, あるいは両者ほぼ平行となっている. しかし, $S_{\min }=-3.8,-8.4 \mathrm{~kg} / \mathrm{mm}^{2}$ に対する折線形 $S-N$ 線 の下側部分については平滑試験片の場合と同傾向で, す なわち, 弾性的ひずみが繰返される場合はこのような性 状を表わすものと考えられる。

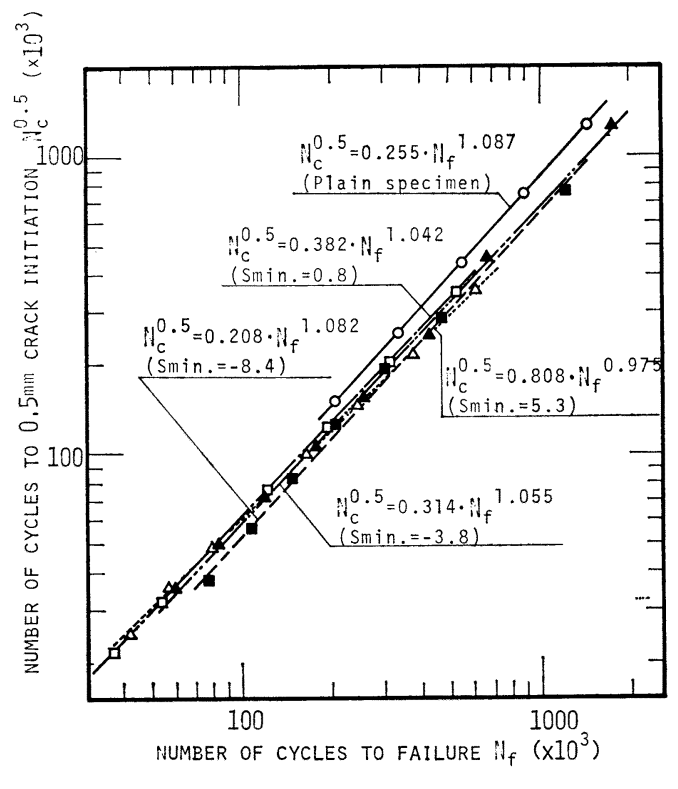

図一8 試験片の $N_{f}$ と $N_{c}^{0.5}$ の関係

図一8 は横軸に $N_{f}$, 縦軸に $N_{c}{ }^{0.5}$ をとも対数目盛 でとり, 平滑および切欠き試験片について基本 $S-N$ 線 から求めた両者の関係を示したものである. $N_{c}{ }^{0.5} / N_{f}$ は平滑試験片および切久き試験片で最大応力 $S_{\max }$ が 比較的低い場合（約 $17 \mathrm{~kg} / \mathrm{mm}^{2}$ 程度以下）に寿命の増 大とともに増加し， $S_{\max }$ がそれ以上ではあまり変ら ない, かっ, その值は本実験範囲では平滑試験片で $0.74 \rightarrow 0.88$ (疲れ限度に近い場合) となり, この傾向は $\mathrm{Schijve}^{34)}$ のアルミ合金板についての実験でも示されて いる. また，切欠き試験片では一般に 0.6 前後, $S_{\text {max }}$ の低下とともに 0.7 程度の值となっている. Klima ${ }^{35)}$ は環状 V切欠き試験片の両振り軸応力実験加もっと微 小なきれつはさらに早い時点から発生すると述べてお り,これらょり切欠き試験片の $N_{c} / N_{f}$ は切欠きの鋭さ にもよるが平滑試験片の場合より相当小さいものとな る.

\section{4. 二段二重応力に対する疲れ寿命予測}

\section{（1）累積繰返し数比の性状}

二段二重回転曲げ応力実験 で求めたきれつ発生寿命 $N_{c}$, 破断寿命 $N_{f}$ を表一2 に, また, 軸応力による一 定応力範囲, 一定最小応力各実験 で求めた $N_{c}, N_{f}$ を 表一3, 4 に示す. きれつ発生については,きれつ長 0.2 , 0.5 および $1.0 \mathrm{~mm}$ (軸応力の場合を除く) に応対する 寿命を考慮し, 寿命推定に使用したきれつ進展曲線お よび各測点との関倸の一例を 図一6 (b), 7 (b), (c) に 
示す.

表一2４ に示された 寿命測定值と基本 $S-N$ 線の方

表一2 二段二重回転曲げ応力による疲れ寿命 (平滑試験片)

\begin{tabular}{c|c|c|c|c|c|c|c}
\hline 種 & \multirow{2}{*}{$\begin{array}{c}S_{1} \\
\left(\mathrm{~kg} / \mathrm{mm}^{2}\right)\end{array}$} & $\begin{array}{c}S_{2} \\
\left(\mathrm{~kg} / \mathrm{mm}^{2}\right)\end{array}$ & $\begin{array}{c}n_{1} \\
\left(10^{3}\right)\end{array}$ & \multicolumn{4}{|c}{ 疼 れ 寿命 $\left(10^{3}\right)$} \\
\cline { 5 - 8 } 別 & $N_{c}{ }^{0.2}$ & $N_{c}{ }^{0.5}$ & $N_{c}^{1}$ & $N_{f}$ \\
\hline & & & 480 & 588 & 604 & 617 & 685 \\
$\mathrm{~L}$ & & 500 & 605 & 624 & 639 & 712 \\
$\dot{\mathrm{H}}$ & 24.7 & 27.1 & 640 & 699 & 722 & 741 & 818 \\
試 & $\left(1.02 S_{0}\right)$ & $\left(1.12 S_{0}\right)$ & 740 & 814 & 824 & 831 & 903 \\
験 & & & 850 & 887 & 911 & 930 & 1011 \\
& & & 900 & 937 & 955 & 969 & 1041 \\
\hline $\mathrm{H}$ & & & 68 & 760 & 777 & 790 & 850 \\
$\dot{\mathrm{L}}$ & 27.1 & 24.7 & 102 & 482 & 498 & 511 & 598 \\
試 & $\left(1.12 S_{0}\right)$ & $\left(1.02 S_{0}\right)$ & 140 & 210 & 231 & 249 & 301
\end{tabular}

（注） $\mathrm{H}-\mathrm{L}$ 試験各 $n_{1}$ ごとの棒命測定值は, 2 実験値の平均を示す。
程式とから，式 (3)，(4) よりきれつ発生および破断寿 命について累積繰返し数比を算定したものを図一9 お よび 表一3，4 の右側欄に示寸.

$$
\begin{aligned}
& \sum n / N_{c}=n_{1} / N_{c 1}+n_{2} / N_{c 2} \\
& \sum n / N_{f}=n_{1} / N_{f_{1}}+n_{2}{ }^{\prime} / N_{f 2}
\end{aligned}
$$

\section{ここに, $n_{1}$ : 一次応力の繰返し数}

$n_{2}, n_{2}{ }^{\prime}$ : 一次応力を二次応力に切換えたのち, 所

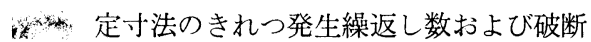
までの繰返し数

$N_{c 1}, N_{f_{1}}$ : 基本 $S-N_{c}, S-N_{f}$ 線から求めた一次灾 力汇対する所定小法きれつ発生寿命およ び破断寿命

$N_{c 2}, N_{f 2}$ : 上と同様に二次応力に対するもの

図一9 は横軸汇 $\sum n / N$, 綐軸に $n_{1}$ をとり, 表一2に

\begin{tabular}{|c|c|c|c|c|c|c|c|c|c|c|}
\hline \multirow{2}{*}{$\begin{array}{c}S_{r} \\
\left(\mathrm{~kg} / \mathrm{mm}^{2}\right)\end{array}$} & \multirow{2}{*}{ 試験種別 } & \multirow{2}{*}{$\begin{array}{c}S_{\text {min } 1} \\
\left(\mathrm{~kg} / \mathrm{mm}^{2}\right)\end{array}$} & \multirow{2}{*}{$\begin{array}{c}S_{\min 2} \\
\left(\mathrm{~kg} / \mathrm{mm}^{2}\right)\end{array}$} & \multirow{2}{*}{$\begin{array}{c}n_{1} \\
\left(10^{3}\right)\end{array}$} & \multicolumn{3}{|c|}{ 疲れ寿命 $\left(10^{3}\right)$} & \multicolumn{3}{|c|}{ 累積繰返し数比 } \\
\hline & & & & & $N_{c}^{0.2}$ & $N_{c}^{0.5}$ & $N_{f}$ & $\sum n / N_{c}^{0.2}$ & $\sum n / N_{c}^{0.5}$ & $\sum n / N_{f}$ \\
\hline \multirow{2}{*}{28.2} & $\mathrm{~L}-\mathrm{H}$ & -8.4 & 0.8 & 30 & 31 & 36 & 63 & 0.96 & 1.04 & 1.28 \\
\hline & $\mathrm{H}-\mathrm{L}$ & 0.8 & -8.4 & 15 & 24 & 28 & 53 & 1.07 & 1.02 & 0.89 \\
\hline \multirow{2}{*}{26.6} & $\mathrm{~L}-\mathrm{H}$ & -8.4 & 0.8 & 42.5 & 44 & 52 & 90 & 0.91 & 1.05 & 1.29 \\
\hline & $\mathrm{H}-\mathrm{L}$ & 0.8 & -8.4 & 20 & 38 & 42 & 67 & 1.08 & 1.01 & 0.81 \\
\hline \multirow{6}{*}{25.1} & & & & 25 & 54 & 65 & 134 & 1.02 & 1.00 & 1.53 \\
\hline & L-H & -8.4 & 0.8 & 50 & 62 & 69 & 119 & 0.97 & 0.99 & 1.20 \\
\hline & & & & 60 & 60 & 65 & 118 & 1.08 & 1.13 & 1.21 \\
\hline & & & & 15 & 45 & 51 & 99 & 0.76 & 0.75 & 0.75 \\
\hline & $\mathrm{H}-\mathrm{L}$ & 0.8 & -8.4 & 27.5 & 48 & 52 & 86 & 0.92 & 0.86 & 0.74 \\
\hline & & & & 40 & 46 & 51 & 77 & 1.01 & 0.96 & 0.75 \\
\hline \multirow{6}{*}{22.1} & & & & 55 & 100 & 119 & 199 & 0.81 & 0.93 & 1.06 \\
\hline & L-H & -8.4 & 5.3 & 110 & 150 & 163 & 244 & 1.07 & 1.11 & 1.18 \\
\hline & & & & 175 & 162 & 188 & 274 & 1.00 & 1.06 & 1.18 \\
\hline & & & & 24 & 116 & 134 & 231 & 0.79 & 0.83 & 0.83 \\
\hline & $\mathrm{H}-\mathrm{L}$ & 5.3 & -8.4 & 47.5 & 93 & 106 & 191 & 0.78 & 0.80 & 0.76 \\
\hline & & & & 70 & 66 & 73 & 139 & 0.78 & 0.71 & 0.65 \\
\hline
\end{tabular}

表一3 二段二重軸応力（一定応力範囲）による疲れ寿命と累積繰返し数比（切火き試験片）

\begin{tabular}{|c|c|c|c|c|c|c|c|c|c|c|}
\hline \multirow{2}{*}{$\begin{array}{c}S_{\mathrm{min}} \\
\left(\mathrm{kg} / \mathrm{mm}^{2}\right)\end{array}$} & \multirow{2}{*}{ 試験種別 } & \multirow{2}{*}{$\begin{array}{c}S_{r 1} \\
\left(\mathrm{~kg} / \mathrm{mm}^{2}\right)\end{array}$} & \multirow{2}{*}{$\begin{array}{c}S_{r_{2}} \\
\left(\mathrm{~kg} / \mathrm{mm}^{2}\right)\end{array}$} & \multirow{2}{*}{$\begin{array}{c}n_{1} \\
\left(10^{3}\right)\end{array}$} & \multicolumn{3}{|c|}{ 疲れ陦命 $\left(10^{3}\right)$} & \multicolumn{3}{|c|}{ 罢積繰返 し 数比 } \\
\hline & & & & & $N_{c}^{0.2}$ & $N_{c}^{0.5}$ & $N_{f}$ & $\sum n / N_{c}^{0.2}$ & $\sum n / N_{c}^{0.5}$ & $\sum n / N_{f}$ \\
\hline \multirow{2}{*}{0.8} & $\mathrm{~L}-\mathrm{H}$ & 25.1 & 28.2 & 27.5 & 36 & 40 & 64 & 1.09 & 1.15 & 1.33 \\
\hline & $\mathrm{H}-\mathrm{L}$ & 28.2 & 25.1 & 15 & 29 & 36 & 64 & 1.12 & 1.11 & 1.01 \\
\hline \multirow{6}{*}{-3.8} & & & & 22.5 & 34 & 40 & 72 & 0.72 & 0.81 & 1.03 \\
\hline & $\mathrm{L}-\mathrm{H}$ & 25.1 & 28.2 & 45 & 53 & 60 & 94 & 0.96 & 0.99 & 1.21 \\
\hline & & & & 65 & 67 & 73 & 99 & 1.07 & 1.13 & 1.19 \\
\hline & & & & 10 & 44 & 52 & 95 & 0.85 & 0.87 & 0.88 \\
\hline & H- L & 28.2 & 25.1 & 20 & 41 & 48 & 87 & 0.97 & 0.95 & 0.90 \\
\hline & & & & 26 & 31 & 39 & 74 & 0.96 & 0.92 & 0.84 \\
\hline \multirow{6}{*}{-8.4} & & & & 180 & 203 & 210 & 258 & 0.94 & 1.07 & 1.14 \\
\hline & $\mathrm{L}-\mathrm{H}$ & 19.0 & 28.2 & 380 & 399 & 405 & 452 & 1.09 & 1.13 & 1.24 \\
\hline & & & & 480 & 488 & 494 & 547 & 0.90 & 0.98 & 1.24 \\
\hline & & & & 15 & 377 & 435 & 655 & 0.95 & 0.92 & 0.72 \\
\hline & $\mathrm{H}-\mathrm{L}$ & 28.2 & 19.0 & 30 & 208 & 240 & 555 & 1.15 & 1.03 & 0.81 \\
\hline & & & & 33 & 156 & 170 & 489 & 1.16 & 1.01 & 0.79 \\
\hline
\end{tabular}

表一4 二段二重軸応力（一定最小応力）による疲れ寿命と累積繰返し数比（切欠き試験片） 


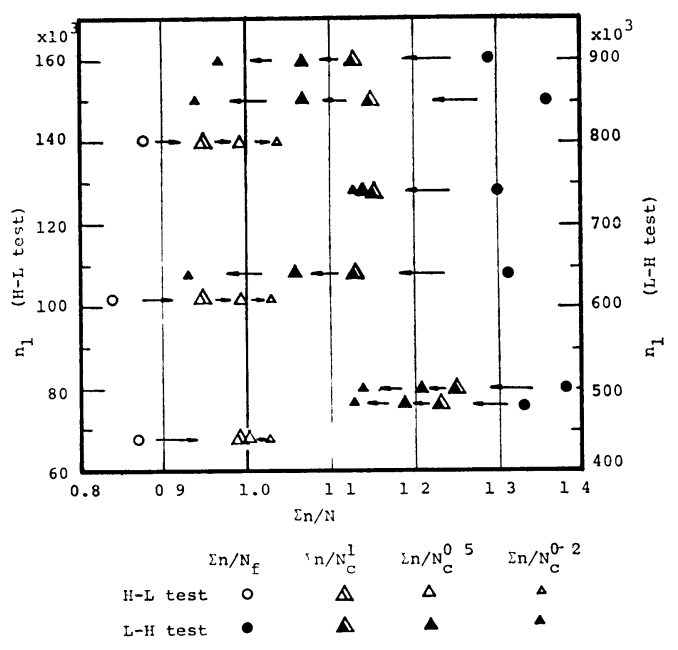

図一9破断寿命およびきれつ発生夷命についての 蒸积繰返し数比（二段二重回転曲げ応力）

示す各実騃ごとの $\sum n / N_{c} . \sum n / N_{f}$ をプロントしたも のである. $\sum n / N_{f}$ は従来からよく知られるごとく ${ }^{8)}$, $\mathrm{L}-\mathrm{H}$ 試験で $\sum n / N_{f}>1 . \mathrm{H}-\mathrm{L}$ 試験で $\sum n / N_{f}<1$ と なっている これに対し $\sum n / N_{c}$ は基準とするきれつ長 を $10,05,0.2 \mathrm{~mm}$ と小とするに従い, L-H 試験で $\sum n / N_{f}$ より 1 側一順次小さくなり $\left(\sum n / N_{c}{ }^{0}{ }^{2}\right.$ は 1 よ り小となるものもある), $\mathrm{H}-\mathrm{L}$ 試験で $\Sigma n / N_{f}$ より 1 側人順次大きくなる $\left(\sum n / N_{c}{ }^{02}\right.$ は 1 をわずかに 超過し た).このように $\mathrm{L}-\mathrm{H}, \mathrm{H}-\mathrm{L}$ 試験における $\Sigma n / N_{c}$ は 基準きれつ長を小にとるに従い 1 に対し両側から接近し
てゆく性状が明らかとなったが，このことは回転曲げ応 力のみならず 表一3，4 に示すごとく軸応力が作用する 場合の $\sum n / N$ についてもまったく同様である. また，同 表より破断寿命および $05,02 \mathrm{~mm}$ きれつ発生寿命ご とに求めた $\sum n / N$ を, 一次応力の繰返し 数比 $n_{1} / N_{1}$ との関係で示したのが 図一10 であるが, 実験值のばら つきもあり，両者間にあまりはっきりした関係は認 められなかった. いま, 基準きれつ長の相違による $\sum n / N$ の増減傾向を求めるため, 各対象寿命ごとに $\sum n / N$ の単純平均と, その標準偏差を L-H, H-L 試 験ごとにとってみる. $\sum n / N$ の平均值は 図中に 示すご とく, $\mathrm{L}-\mathrm{H}$ 試験では $\sum n / N_{f} \rightarrow \sum n / N_{c}{ }^{05} \rightarrow \sum n / N_{c}{ }^{02}$ の順序に減少し， H-L 試験ではこれと同じ順序に増加 している. L-H，H-L 試験における各平均值が互いに 一番接近しているのは, きれつ長 $02 \mathrm{~mm}$ に対するも のでその值も 1 にごく近く，この場合は応力履歴の影響 がほとんど認められなくなっている．標準偏差について は L-H, H-L 試験とも一般に $\sum n / N_{c}{ }^{0}{ }^{5} \rightarrow \sum n / N_{c}{ }^{2}{ }^{2}$ の順序に増大し, 微小きれつの測定に誤差がはいりやす いことを示している.

$02 \mathrm{~mm}$ あるいはそれ以下の微小きれつを正確に測定 することができれば標準偏差が減少し，きれつ発生寿命 を直線被害則によりかなり精度よく予測することが可能 であると考えられる. なお， $0.5 \mathrm{~mm}$ きれつを基準とし ても予測精度がそれほどおちることはなく，また，少な くとも破断を基準とする寿命予測より優れていることは 明らかであろう。

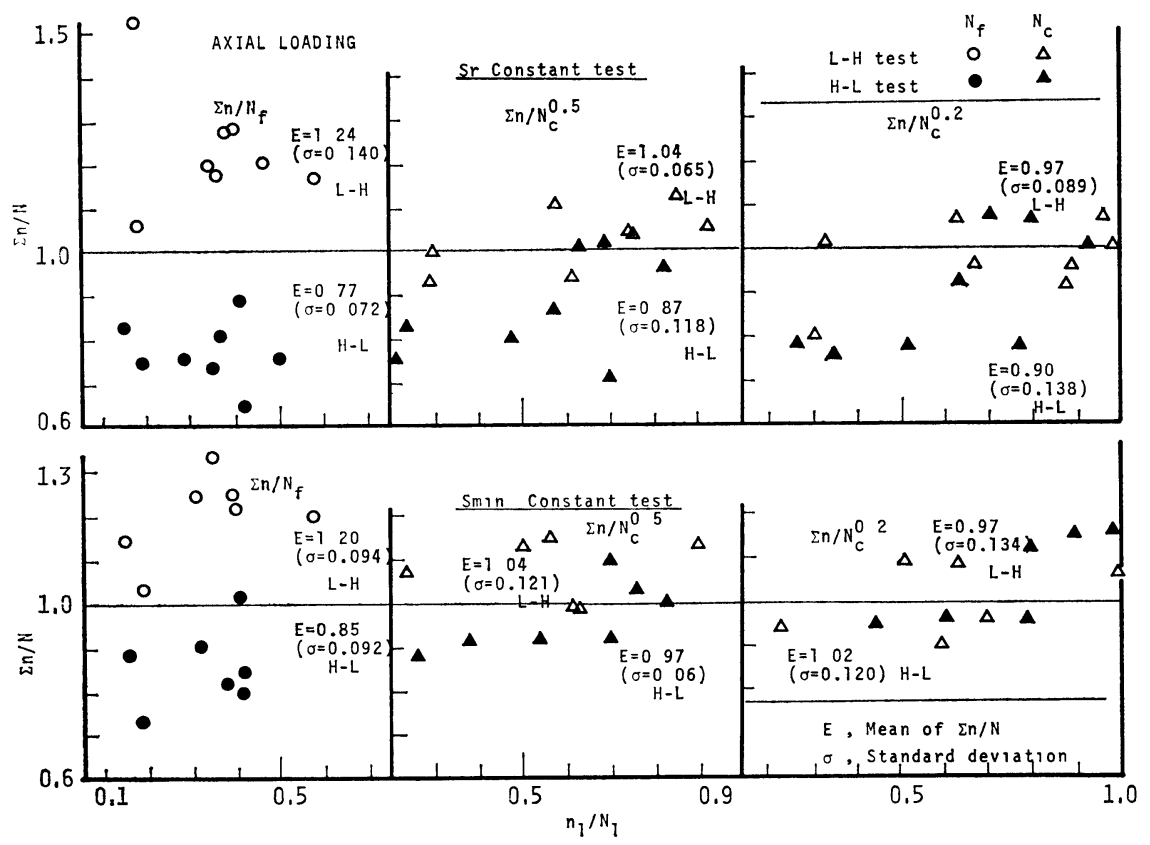

図-10 一次応力の綠返し数比と累䅡絿返し数比（二段二重軸応力） 


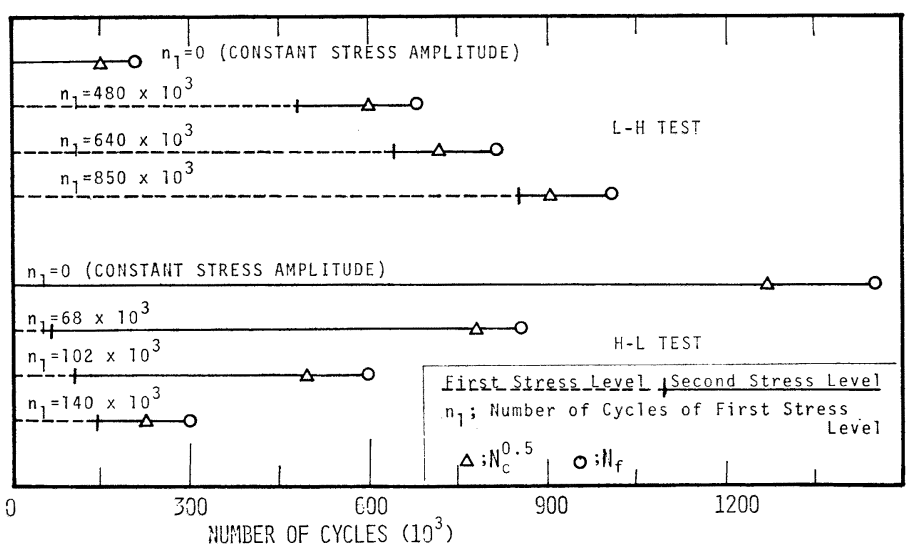

図-11 一次応力の繰返し数と疲れ寿命（二段二重回転曲げ， $S=24.7,27.1 \mathrm{~kg} / \mathrm{mm}^{2}$ )
し， L-H 試験ではあまり 差違が生じて いない。これより， $n / N_{f}$ は二次応力に 対するものが $\mathrm{L}-\mathrm{H}$ 試験では大きく, $n_{1}$ の小なる場合は 1 に近いものがあり，ま た， $\mathrm{H}-\mathrm{L}$ 試験では小さく, $n_{1}$ の増大に つれ急速減少するなど, 従来から知ら れる L-H 試験で $\sum n / N_{f}>1, \mathrm{H}-\mathrm{L}$ 試 験で $\sum n / N_{f}<1$ となる 関係の主要因 と考えられる（ただし，きれつ発生前に 二次応力が作用).これに対し $n / N_{c}$ は 二次応力に対するものが $\mathrm{L}-\mathrm{H}$ 試験では 破断寿命の場合に比し相当小さく, H-L 試験ではそれを下回る程度のものとなっ ている

\section{（2）一次応力の繰返しと疲れ寿命}

一次応力の 繰返し数 $n_{1}$ が $0.5 \mathrm{~mm}$ きれつ発生寿命 $N_{c}{ }^{0.5}$ および破断寿命 $N_{f}$ に及ぼす影響を求めるため, 両者の関倸の一例を 図一11 に示したが，回転曲げ応力 と軸応力とにかかわらず，一般に以下の傾向を示してい る.すなわち, 一次応力を二次応力に切換えてからきれ つ長が $0.5 \mathrm{~mm}$ になるまでの繰返し数 $\left[N_{c}^{0.5}-n_{1}\right]$ は, 一次応力の影響をうけ, 最初から二次応力のみによる場 合 $\left(n_{1}=0\right)$ の $N_{c}^{0.5}$ より減少し，かつ $n_{1}$ が大になる ほど減少する程度が大きく，また，この傾向は $\mathrm{H}-\mathrm{L}$ 試 験で顕著で，このことは $\mathrm{H}$ 試験時材料の 損傷が進めば L試験でもそれが急進することを示している．また， $0.5 \mathrm{~mm}$ きれつが発生してから 破断に至るまでのきれつ進展寿 命 $\left[N_{f}-N_{c}{ }^{0.5}\right]$ は, 二次応力 のみによる場合のきれつ進展寿 命に比し，L-H 試験ではやや 大きく, H-L 試験ではかなり 小となっている.なお, $n_{1}$ の多 少によるきれつ進展寿命の相違 はあまり認められず，すなわ ち,ひとたびきれつが発生すれ ば以後のきれつ進展寿命は $n_{1}$ の多少にはあまり影響されない ものと考えられる。

これらの結果から,一次応力 を二次応力に切換えてから破断 までの絽返し数 $\left[N_{f}-n_{1}\right]$ と， 二次応力のみによる場合の $N_{f}$ との関倸は，前者の方が小では あるが $n_{1}$ の増加とともに $\mathrm{H}-\mathrm{L}$ 試験では両者の差は急速に拡大

\section{5. プログラム応カによる疲れ寿命}

\section{（1）二次波をもつ回転曲げ応力による疲れ寿命}

a) 疲れ寿命の計算

図一3 (c) に示す方形および三角二次波をもつ回転曲 げ応力が作用する場 合，直線被害則が成立するとすれ ば，基本 $S-N$ 線式と積算応力頻度分布曲線から後述の ごとくその疲れ寿命を計算することができる．この場 合, 過小応力の取り扱いが問題となるが，疲れ寿命に影 響を及ぼす応力として疲れ限度の $80 \%{ }^{36)}$ 以上のものを 考慮することとすれば，本実験での最小応力はすべてこ
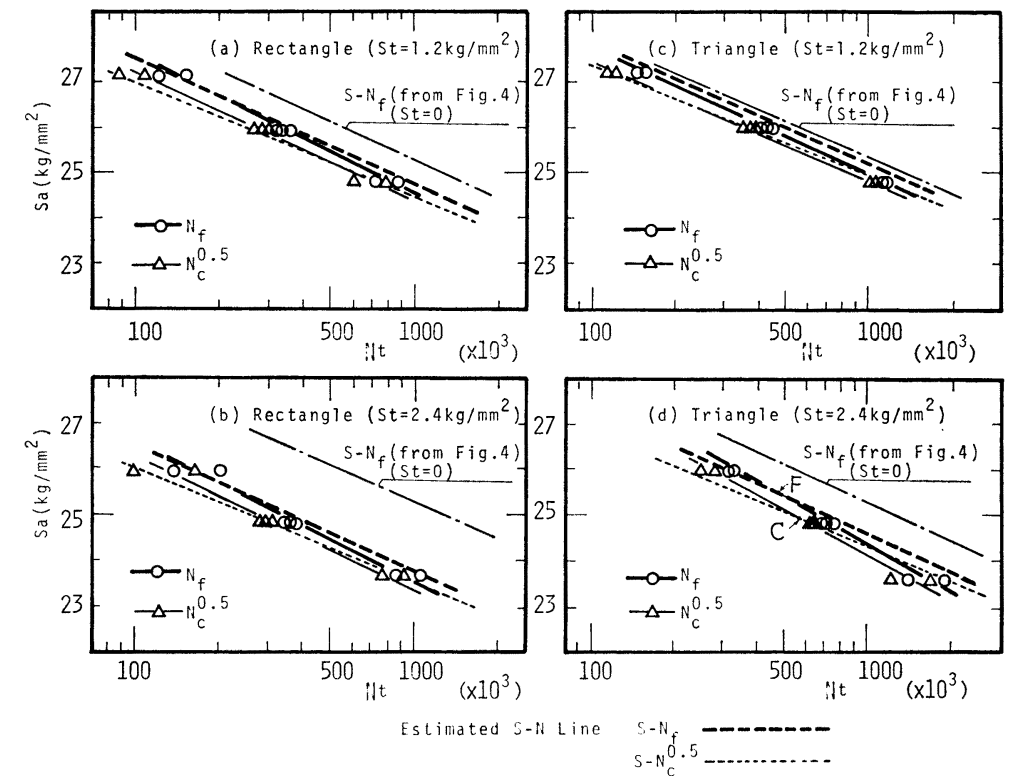

図一12 方形および三角二次波をもつ回転曲げ応力による 疲れ寿命の計算値と実験値 
れを上回るので，全作用応力に対し式（7）を適用する ことにする。

いま, 積算応力頻度分布曲線 ( 1 周期) の応力振幅を $S_{n}$, 積算応力頻度数を $n$ とすれば,

$$
\begin{aligned}
& \text { 方形二次波 : } S_{n}=S_{a} \pm S_{t}, \quad\left(n=n_{c} / 2 \text { 時 }+\rightarrow-\right) \\
& \text { 三角二次波 : } S_{n}=S_{a}+S_{t}-2 S_{t} \dot{n} / n_{t}
\end{aligned}
$$$$
\text { ここに, }
$$

回転曲げ応力に対する基本 $S-N$ 線式を次式で表わ す.

$1 / N=e^{A S_{n}+D}$

$A, D$ 流 $S-N$ 線の種別に応じ 図一4 上り求められる. 対象応力下での疲れ寿命を $N_{t}$, 疲れ破壊までの二次 波の重複数を $Z$ とすれば, 寿命算式は式 (8) で与えら れる。

$$
N_{t}=Z \cdot n_{c}=n_{c} / \int_{0}^{n_{c}} \frac{d n}{N}=n_{c} / \int_{0}^{n_{c}} e^{A S_{n}+D} d n
$$

すなわち, 方形二次波をもつ回転曲げ応力に対しては,

$$
N_{t}=\frac{2}{e^{A S_{1}+D}+e^{A S_{2}+D}}
$$

三角二次波をもつ回転曲げ応力に対しては，

$$
N_{t}=\frac{2 A S_{t}}{e^{A S_{1}+D}-e^{A S_{2}+D}}
$$

ここに,

$$
S_{1}=S_{a}+S_{t}, S_{2}=S_{a}-S_{t}
$$

図一12 に破線で示すものは式 (9),(10) より $0.5 \mathrm{~mm}$ きれつ発生抢よび破断寿命について計算したもので, 綎 軸に $S_{a}$, 横軸に寿命 $N_{t}$ (対数)をとっている. 計算 $S-N$ 線は基本 $S-N$ 線に対し，いずれも平行かつその
下側に位置し，また，二次波の $S_{a}, S_{t}$ が同じなら方形 二次波の方が三角二次波より，同種二次波では $S_{a}$ が同 一の場合 $S_{t}$ の増大とともに疲れ寿命は減少する。な お，この性状は b) で述べる実験で確認された。

b) 疲れ寿命の測定と累積繰返し数比

2.(3)で述べた方形および三角二次波をもつ回転曲げ 応力実験で求めたきれつ発生寿命 $N_{c}$, 破断寿命 $N_{f}$ を 表一5 に示す.きれつ発生については，きれつ長 0.2 , 0.5 および $1.0 \mathrm{~mm}$ に対応する 寿命を考慮し, 寿命推 定に使用したきれつ進展曲線および各測点との関係の一 例を 図一6 (c) に示す. 各実験で求めた $N_{c}^{0.5}, N_{f}$ を 図一12にプロットするとともに，これら実験值に対し 最小二乗法で算定した実験 $S-N$ 線を同図に実線であわ せ示した. 実験 $S-N$ 線は計算 $S-N$ 線に比較的よく接 近しているが，一般に計算線より勾配が やや急となり (1/0.8 1/0.92 倍), Corten-Dolan ${ }^{9)}$ の提案に近いも のとなっている. また, 実験線と計算線 とは $N_{f}$ に対 するものが $S_{a}=26 \sim 27 \mathrm{~kg} / \mathrm{mm}^{2}$ (これは最大応力で材 料の降伏点に近い值となる) 以上で, $N_{c}{ }^{0.5}$ に対するも のが $S_{a}=25 \sim 26 \mathrm{~kg} / \mathrm{mm}^{2}$ 付近でほぼ同じ角度で交差す る傾向が認められる.このことは同一応力状態で寿命実 測值と計算値の比が, 破断よりきれつ発生で一般に大き くなることを示している.

表一5 に示された寿命測定值から累積繰返し数比を算 定したものを同表右側欄にあわせ示す. $\Sigma n / N_{c}, \Sigma n / N_{f}$

\begin{tabular}{|c|c|c|c|c|c|c|c|c|c|c|}
\hline \multirow{2}{*}{ 応力系 } & \multirow{2}{*}{$\begin{array}{c}S_{t} \\
\left(\mathrm{~kg} / \mathrm{mm}^{2}\right)\end{array}$} & \multirow{2}{*}{$\begin{array}{c}S_{a} \\
\left(\mathrm{~kg} / \mathrm{mm}^{2}\right)\end{array}$} & \multicolumn{4}{|c|}{ 疲 れ 寿 命 $\left(10^{3}\right)$} & \multicolumn{4}{|c|}{ 累積繰返 乙 数比 } \\
\hline & & & $N_{c}^{0.2}$ & $N_{c}^{0.5}$ & $N_{c}^{1}$ & $N_{f}$ & $\sum n / N_{c}^{0.2}$ & $\sum n / N_{c}^{0.5}$ & $\sum n / N_{c}^{1}$ & $\sum n / N_{f}$ \\
\hline \multirow{6}{*}{$\begin{array}{l}\text { 方 } \\
\text { 形 } \\
\frac{\text { 次 }}{\text { 海 }}\end{array}$} & \multirow{3}{*}{1.2} & 27.1 & 89 & 99 & 107 & 136 & 1.05 & 1.03 & 1.05 & 1.02 \\
\hline & & 25.9 & 270 & 285 & 295 & 339 & 1.06 & 1.03 & 1.04 & 0.95 \\
\hline & & 24.7 & 670 & 694 & 713 & 797 & 0.89 & 0.88 & 0.89 & 0.84 \\
\hline & \multirow{3}{*}{2.4} & 25.9 & 124 & 133 & 140 & 170 & 1.30 & 1.24 & 1.24 & 1.14 \\
\hline & & 24.7 & 290 & 302 & 312 & 361 & 1.05 & 0.99 & 0.99 & 0.90 \\
\hline & & 23.5 & 806 & 833 & 855 & 967 & 0.98 & 0.95 & 0.97 & 0.91 \\
\hline \multirow{6}{*}{$\begin{array}{l}\text { 皇 } \\
\cdots \\
\text { 次 } \\
\text { 波 }\end{array}$} & \multirow{3}{*}{1.2} & 27.1 & 109 & 118 & 125 & 154 & 0.94 & 0.91 & 0.92 & 0.88 \\
\hline & & 25.9 & 355 & 370 & 383 & 440 & 1.03 & 1.00 & 1.02 & 0.95 \\
\hline & & 24.7 & 1037 & 1059 & 1076 & 1151 & 1.02 & 1.00 & 1.02 & 0.93 \\
\hline & \multirow{3}{*}{2.4} & 25.9 & 254 & 271 & 284 & 331 & 1.16 & 1.17 & 1.18 & 1.08 \\
\hline & & 24.7 & 657 & 671 & 682 & 747 & 1.06 & 1.02 & 1.02 & 0.91 \\
\hline & & 23.5 & 1458 & 1492 & 1519 & 1662 & 0.85 & 0.79 & 0.81 & 0.72 \\
\hline
\end{tabular}
は $S_{a}$ の増大とともに大きくなり 1 をこえるものも認め られる. 各実験では $\sum n / N_{c}$ は $\sum n / N_{f}$ より常に大と なり，これは 4. (1)で述べた二段二重応力下の $\sum n / N_{c}$ と $\sum n / N_{f}$ の関係とは異なる傾向を示している. 図一 12 (たとえば (d) 図からもらかがわれるごとく，C点以 下 $\left(\sum n / N_{c} \leqq 1\right)$ では $\sum n / N_{c}$ は $\sum n / N_{f}$ より 1 に接 近はするが， $S_{a}$ の減少とともに 1 との差は桩大し，ま

表一5 方形および三角二次波をもつ回転曲げ応力による疲れ寿命と累積繰返し数比

（注） 寿命測定值は $S_{t}=1.2 \mathrm{~kg} / \mathrm{mm}^{2}, S_{a}=25.9 \mathrm{~kg} / \mathrm{mm}^{2}$ および $S_{t}=2.4 \mathrm{~kg} / \mathrm{mm}^{2}, S_{a}=24.7 \mathrm{~kg} / \mathrm{mm}^{2}$ に対するもの（いずれもプロ グム化対象応力）: 3 実験值の平均，它の他は 2 夷験值の平均を示す。 
張・兰木・西村 :

た, $\mathrm{F}$ 点以上 $\left(\sum n / N_{f} \geqq 1\right)$ では $\sum n / N_{c}$ は $\sum n / N_{f}$ よりさらに大となる. $\mathrm{F}, \mathrm{C}$ 点間では $S_{a}$ が C 点側に近 いときは $\Sigma n / N_{c}$ が, $\mathrm{F}$ 点側に近いときは $\sum n / N_{f}$ が より 1 に接近することになる.

基準きれつ長と $\Sigma n / N_{c}$ との関係については 表一5 に示す方形および三角二次波ごとの $\sum n / N$ の単純平均 值 (かっこ内は三角二次波) が $\sum n / N_{c}^{0.2}=1.06(1.01)$, $\sum n / N_{c}{ }^{0.5}=1.02(0.98), \Sigma n / N_{c}{ }^{1}=1.03(1.00), \Sigma n / N_{f}$ $=0.96(0.91)$ となるごとく, きれつ長を小とするに従 い $\Sigma n / N_{c}$ の微増傾向が認められる.

実際, 鋼部材では平滑材で作用最大応力は材料の降伏 点以下となるから $\sum n / N_{f}<1$ となり, この条件下で きれつ発生寿命を直線被害則で計算すれば破断寿命に対 して行うより予測精度は一般によくなるものと考えられ る.ただし, この状態がより一般的である作用応力が過 小応力領域に多い場合は, きれつ発生寿命について計算
しても予測誤差が大きくなるおそれがある.

\section{（2）プログラム応力による疲れ寿命}

a) 応力ブロック数と疲れ寿命

2. (3) で述べた二段多重系および五段多重系プログラ 么応力実験で求めたきれつ発生寿命 $N_{c}$, 破断寿命 $N_{f}$ を表一6に示す. きれつ発生については, きれつ長 $0.2,0.5$ および $1.0 \mathrm{~mm}$ に対応する寿命を考虑し, 寿 命推定に使用したきれつ進展曲線および各測点との関係 の一例を 図一6 (d) に示す.なお,この実験においては 作用応力の関係できれつが定常的に進展しない場合があ り, 実測值のない $0.2 \mathrm{~mm}$ きれつ発生寿命をきれつ進 展曲線から外插で求めることは, 特に二段多重系応力で 問題があり，今後補足を要するものと考えられる.

表一6 より1応力ブロックにおける一次波の綝返し数 $n_{0}$ と $N_{c}{ }^{0.5}, N_{f}$ との関釈を 図一13 に示す. 各測点に

表一6 プログラム応力による疲れ寿命と累䖽綠返し数比

(a) 二段多重系

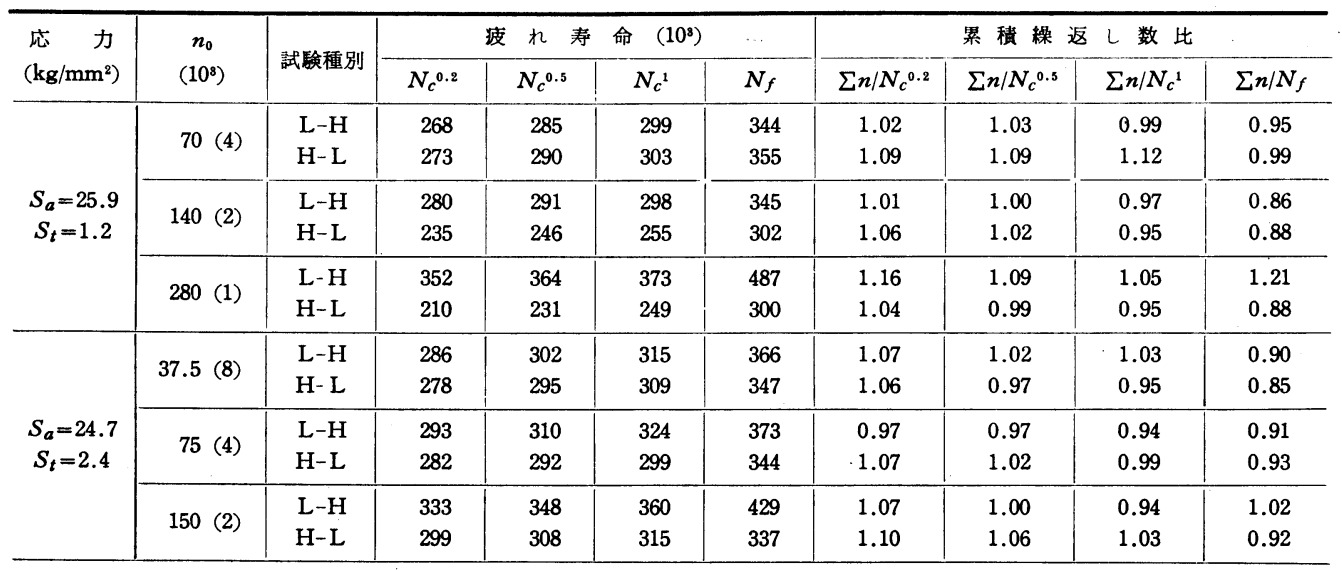

(b) 五段多重系

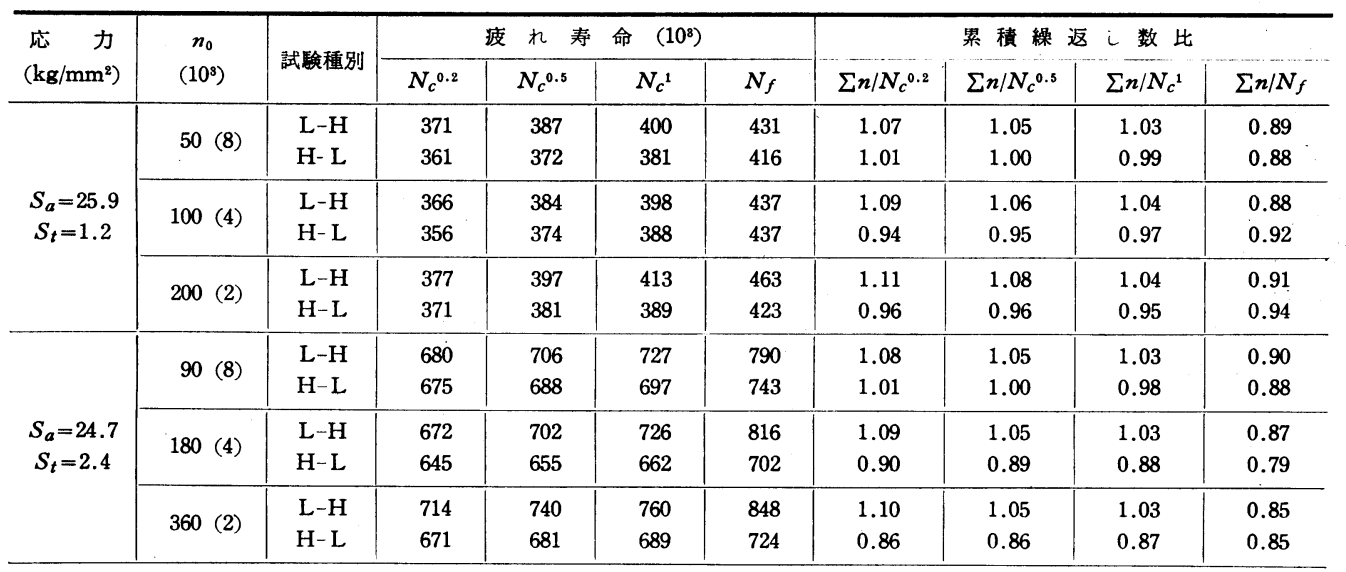

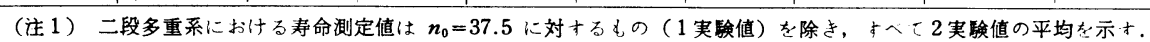

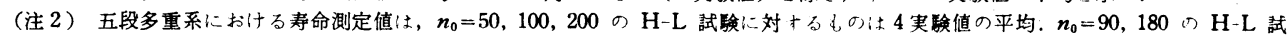
験に対するれのは 3 実験值の平均, その他は 2 実験值の平均を示す.

（注 3） $n_{0}$ 欄の（）内数字は設定ブロック数である. 


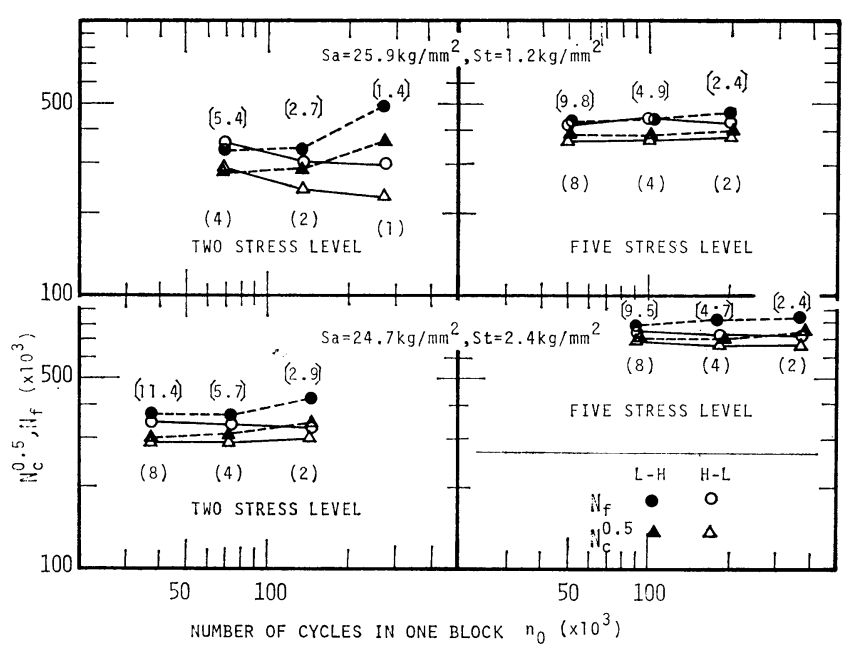

図-131 応カブロックの繰返し数と疲れ寿命

表一7 プログラム応力下および対象変動応力下での $N_{c}{ }^{0.5}, N_{f}$

\begin{tabular}{|c|c|c|c|c|c|c|c|c|}
\hline \multirow{2}{*}{$\begin{array}{l}\text { 底 } \\
\text { 菜 } \\
\text { 種 } \\
\text { 別 }\end{array}$} & \multirow{2}{*}{$\begin{array}{c}S_{t} \\
\left(\mathrm{~kg} / \mathrm{mm}^{2}\right)\end{array}$} & \multirow{2}{*}{$\begin{array}{c}S_{a} \\
\left(\mathrm{~kg} / \mathrm{mm}^{2}\right)\end{array}$} & \multicolumn{2}{|c|}{$\begin{array}{l}0.5 \mathrm{~mm} \text { きれ } \\
\text { 発生寿命 }\end{array}$} & \multirow{2}{*}{$\frac{N_{c 0}{ }^{0.5}}{N_{c e^{0.5}}}$} & \multicolumn{2}{|c|}{ 破断 寿命 } & \multirow{2}{*}{$N_{f o} / N_{f e}$} \\
\hline & & & $\begin{array}{l}N_{c 0} 0.5 \\
\left(10^{3}\right)\end{array}$ & $\begin{array}{l}N_{c e^{0.5}} \\
\left(10^{3}\right)\end{array}$ & & $\begin{array}{l}N_{f_{0}} \\
\left(10^{3}\right)\end{array}$ & $\begin{array}{l}N_{f e} \\
\left(10^{3}\right)\end{array}$ & \\
\hline 二多 & 1.2 & 25.9 & 288 & 271 & 1.06 & 350 & 332 & 1.05 \\
\hline 段重 & 2.4 & 24.7 & 299 & 315 & 0.95 & 357 & 383 & 0.93 \\
\hline 五多 & 1.2 & 25.9 & 379 & 368 & 1.03 & 437 & 429 & 1.02 \\
\hline 段重 & 2.4 & 24.7 & 697 & 647 & 1.08 & 767 & 741 & 1.03 \\
\hline
\end{tabular}

要に応じ上述のごとき比較的簡単なプログ ラム応力実験を併用することにより精度の よい結果が得られるものと考えられる.

b) 累積繰返し数比の性状

表一6 に示された寿命測定值から $\sum n /$ $N_{c}, \sum n / N_{f}$ を算定し同表右側欄にあわせ 示す. $\sum n / N_{f}$ は二段多重系の1ブロッ ク・ L-H 試験のみ, 二段二重応力状態に 準ずるため 1 より大となるが，その他は二 段多重系と五段多重系とにかかわらず，ま た, L-H, H-L 試験とも 1 より小となり, これは過小応力もきれつ進展に寄与するこ とを示すものと考えられる (1例を除く). また, $\sum n / N_{c}$ は $\sum n / N_{f}<1$ の場合, 常 にそれより值が大となっている.

なお, 二段多重系応力で $S_{a}=25.9 \mathrm{~kg} /$ $\mathrm{mm}^{2}, S_{t}=1.2 \mathrm{~kg} / \mathrm{mm}^{2}$, ブロック数 2,4 の場合, $\sum n / N_{f}$ の平均值 (L-H 試験で 0.91, H-L 試験で 0.94) をこれと同じ応 力振幅をもつ二段二重応力下の $\sum n / N_{f}$ 平均值（表一2 より計算し, L-H 試験で $1.33, \mathrm{H}-\mathrm{L}$ 試験で 0.86) と比較すると, より 1 に接近していることがわかり，ま た, 同じ $S_{a}, S_{t}$ の方形二次波をもつ回転

付した（）内添字は計算きれつ発生寿命に対し設定した ブロック数であり，同じく〔〕内添字は計算破断寿命 を $n_{0}$ で除した值である. 作用応力が二段多重系と五段 多重系とにかかわらず，同じ $n_{0}$ に対し $N_{c}^{0.5}, N_{f}$ とも $\mathrm{H}-\mathrm{L}$ 試験值は L-H 試験值より短寿命で, この傾向はブ ロック数の小なるものに大きい. ブロック数の増加とと もに L-H, H-L 試験值は接近し, ブロック数が $N_{c}^{0.5}$ で 4 8, $N_{f}$ では 5〜9 程度になれば両者はほぼ一致 し, 疲れ寿命に及ぼす高低初応力の作用順序の影響が認 められなくなる.

$\mathrm{L}-\mathrm{H}, \mathrm{H}-\mathrm{L}$ 試験值があい準じてくる場合の $0.5 \mathrm{~mm}$ きれつ発生寿命 $N_{c 0}{ }^{0.5}$ および破断寿命 $N_{f 0}$ (いずれも L-H，H-L 試験值の平均）を 表一7 に示すとともに, プログラム化の対象とした同じ $S_{a}, S_{t}$ の方形および三 角二次波をもつ回転曲げ応力による $0.5 \mathrm{~mm}$ きれつ発 生および破断寿命実測值 $N_{c e} e^{0.5}, N_{f e}$ を図一12 から 求めあわせ示した. $N_{c 0}{ }^{0.5}$ と $N_{c e} e^{0.5}, N_{f 0}$ と $N_{f e}$ は比 較的よい一致を示し, $N_{c 0}{ }^{0.5} / N_{c e} e^{0.5}=0.95 \sim 1.08, N_{f 0} /$ $N_{f e}=0.93 \sim 1.05$ と $\pm 8 \%$ 以内の相違となっている.

すなわち, L-H, H-L 試験值があい準じてくる場合の きれつ発生あるいは破断寿命は, 対象変動応力下のそれ とかなり接近したものとなる.これより変動応力に対す る寿命予測に際し直線被害則による寿命計算に加え, 必
曲げ応力下の $\sum n / N_{f}$ も 0.95 なる值を示している. プ ログラム応力に対する寿命予測もきれつ発生寿命につい て行ったほうが一般に精度がよくなると考えられるが, このような応力変動下では破断寿命を Corten-Dolan ${ }^{9)}$ の考え方を適切に反映して計算することも一方策ではあ る.

\section{6. 結 論}

以上の検討結果よりおもな結論を述べれば次のとおり である。

（1）本研究は従来からの疲れ破断寿命にかわり, 主 としてきれつ発生寿命に着目して, 鋼部材の疲れ寿命予 測などの問題を実験的に検討したものである.この場合 のきれつ発生寿命は, 試験片表面の巨視的きれつの進展 曲線から求めたきれつ長 $0.5 \mathrm{~mm}$ に対応するものを主 体としている.

（2）定応力が作用する場合, きれつ発生寿命 $N_{c}$ に 対する $S-N_{c}$ 線は破断寿命 $N_{f}$ に対する $S-N_{f}$ 線に 比し，一般に緩勾配となり（平行の場合もある），また， $S-N_{c}$ 線は基準きれつ長を小にとるに従い勾配が緩にな ってくる.このため $N_{c} / N_{f}$ は応力振幅あるいは応力範 囲の低下とともに増大し, きれつ長 $0.5 \mathrm{~mm}$ を基準と 
する場合, 平滑試験片（回転曲げ応力下）で $0.7 \sim 0.9$, 円孔切欠き試験片 (軸応力下) で $0.6 \sim 0.7$ 程度の值と なる.

（3）二段二重応力が作用する場合，破断寿命につい ての累積繰返し数比は従来から $\mathrm{L}-\mathrm{H}$ 試験で $\sum n / N_{f}>$ $1, \mathrm{H}-\mathrm{L}$ 試験で $\sum n / N_{f}<1$ となることが知られてい るが，これは二次応力に対する疲れ被害に及ぼす一次応 力の履歴効果によるものである. きれつ発生寿命につい ての累積繰返し数比は基準きれつ長を小とするに従い, $\sum n / N_{f}$ より L-H 試験では 1 側へ順次小さくなり， $\mathrm{H}-\mathrm{L}$ 試験では 1 側一順次大きくなり, 結局 $\sum n / N_{f}$ に 比しより 1 側へ接近したものとなる。したがって, きれ つ発生寿命は直線被害則によりかなり精度よく予測する ことが可能であると考えられる.

（4）二次波をもつ回転曲げ応力およびこれらを対象 としたプログラム応力の場合を含み，作用応力が材料の 降伏点以下の場合はきれつ発生寿命を直線被害則で計算 すれば, 破断寿命に対して行うより予測精度は一般によ くなる.なおこのような応力変動下では，破断寿命を Corten-Dolan の考え方を適切に反映して計算すること も一方策である。

（5）二次波をもつ回転曲げ応力下でのきれつ発生寿 命は作用応力が材料の降伏点をこえる場合, あるいは過 小応力領域に多い場合は予測誤差が大きくなるおそれが あり，これを補足するためプログラム応力実験を取り上 げた．上述回転曲げ応力をそれぞれ二段多重系および五 段多重系応力にプログラム化し, 該応力の計算きれつ発 生寿命を分割したものを 1 ブロックの繰返し数とした. その結果,ブロック数の増加につれ,きれつ発生および破 断寿命の L-H, H-L 試験值は互いに接近し, 両者があ い準じてくるブロック数は, きれつ発生寿命に対し 4 8 となり，破断寿命に対するものはそれより若干多くな る.また,この場合のきれつ発生あるいは破断寿命は, 対象変動応力の寿命実測值とかなりよく一致した.

（6）以上を総括すれば 鋼部材の 疲れ寿命予測に際 し，一般にきれつ発生寿命に対して直線被害則を適用す れば, 従来の破断寿命に対して行うより精度のよい結果 がえられ, また, 予測精度を補うため実際作用応力に対 するプログラム応力を設定し, 疲れ実験を併用すること が望ましいということになる.

\section{謝 辞}

本研究は東京工業大学工学部 中沢 一教授, 吉田 裕 助教授そのほかの方々のご教示とご助言をらけて進めた ものである. また, 実験や関係資料の整理には増田陳紀 助手, 鶴巻正行技官, 荒井国太元技官そのほか研究室の 方々から多大のご協力とご援助をうけた.ここに各位に 対し深甚なる感謝の意を表する次第である.

\section{参考文献}

1）西村俊夫・三木干寿 : 引張応力に起因する鋼橋梁の変状, 土木学会誌, Vol. 61, No. 9, pp. 55 64, 1975-11.

2）西村俊夫：ピソ結合鉄道トラス橋の変状とその対策, 鉄 道技術研究報告, No. 483, 1965-7.

3）日本国有鉄道施設局：建造物の保守证びに健全度䛦断法， 建造物検查資料, pp. 39 42, 1963-5.

4) 土木学会 : 士木建造物の取替標準に閂する研究（国鉄委 託）報告書, pp. 166 173, 1974-3.

5）日本材料学会編：金属の疲学，丸盖，p. 301，1964.

6) Miner, M.A. : Cumulative damage in fatigue, Jour. of Applied Mech., Vol. 12, pp. A 159 164, Sep., 1945 .

7) Kommers, J.B. : The effect of overstressing and understressing in fatigue, Proc., ASTM, Vol. 45, 1945.

8）日本材料試験協会疲労部門委員会：金属材料の重複繰返 応力に対する疲労強度に関する研究, 材料試験, Vol. 8 , No. 72 , pp. 2 43, 1959-9.

9) Corten, H.T. and T.J. Dolan : Cumulative fatigue damage, Inter. Conf. on Fatigue of Metals, pp. 235 $\sim 246$, Sept., 1956 .

10) Corten, H.T. : Application of cumulative fatigue damage theory to farm and construction equipment, SAE, Trans., Vol. 72, pp. 447 466, 1964.

11）中村 宏. 田中真一: 機械の疲れ禁命算出法, 養賢堂, p. $74,1972$.

12）川田雄一・三沢啓志 : 疲爫限度以下の忘力が累積告命に 及ぼす影響，材料，Vol. 17，No. 173，pp. 41〜45，1968 -2 .

13) Grover, H.J. : An observation concerning the cycle ratio in cumulative damage, ASTM, STP, No. 274, pp. 120 124, 1960.

14) Manson, S.S., Freche, J.C. and C.R. Ensign : Application of a double linear damage rule to cumulative fatigue, NASA, TND-3839, Apr., 1967.

15）中沢 一-小林英男：金属の疲れき裂の挙動（8), 機械 の研究, Vol. 20, No. 8, pp. 75 78, 1968-8.

16）青木逸郎・国尾 武・中村 宏 : 実働応力と疲れ強さ（そ の 2 ), 日本機械学会論文集 (第 1 部), Vol. 32 , No. 244, pp. $1762 \sim 1768,1966-12$.

17）萩原・初野・青木・中村・国尾：实働忍力と疲れ強さ(そ の 6 ), 日本機械学会論文集 (第 1 蔀), Vol. 34 , No. 260 , pp. $596 \sim 603,1968-4$.

18）西谷弘信・吉川義久：浅い切欠きをもつ S $20 \mathrm{C}$ 電解研摩 材の二段重複忘力による疲れ被害, 日本機械学会論文集 (第 1 部), Vol. 34, No. 263, pp. 1190 1197, 1968-7.

19）伊藤文人: 実働荷重による鉄道橋の疲労被害推定, 鉄道 技術研究報告, No. 676, 1969-4.

20) Hofmeister, W.F. : Application of the cumulative fatigue damage theory to practical problems, SAE, Trans., Vol. 68, pp. 274 281, 1960.

21）河本 実・柴田俊忍・石川 浩 : プログラム荷重による 疲労強度に及ぼす応力順序の影響, 材料, Vol. 17, No. 173, pp. $21 \sim 25,1968-2$.

22）砂本大造・遠藤忠良 : 実働応力疲労に及ぼす負荷条件の影 響と寿命推定, 材料, Vol. 17, No. 173, pp. 46〜 52, 1968-2.

23) Naumann, E.C., Hardrath, H.F. and D.E. Guthric : Axial-lodd fatigue tests of 2024-T 3 and 7075-T 6 aluminum-alloy sheet specimens under constant and variable amplitude loads, NASA, TND-212, Dec., 1959.

24) Illg, W. : Factors in evaluating fatigue life of struc- 
tural parts, NASA, TND-725, Apr., 1961.

25）田中道七・占城敏莘：ランダム荷重とプログラム荷重に よる軟鋼切欠き材の強度, 材料, Vol. 20, No. 216, pp. 12 17, 1971-9.

26) JIS Z 2274-1974: 金属材料の回転曲げ疲れ試験方法.

27）日本材料学会編：金属材料疲れ陚験便覧, 養賢堂, pp. $22 \sim 23,1968$.

28）西村俊夫・丸山嘉高・荒井国太：正弦, 三角打よび方形 状変動荷重が 作用する場合の軟鋼材の疲れ強さ, 東工大 土木工学科研究報告, No. 9, pp. 109 114, 1970-12.

29）中沢 - - 小林英男：金属の疲れき裂の挙動（4)，機械 の研究, Vol. 20, No. 4, pp. 63 68, 1968-4.

30) Iida, K. : Crack initiation life in low cycle fatigue, 1st. Inter. Symposium of Japan welding Society, pp. A 7.1 7.19, 1971.
31) Liu, H.W. : Crack propagation in thin metal sheet under repeated loading, Jour. of Basic Eng., Trans. of ASME, Mar., 1961.

32）西田正孝：応力集中, 森北出版, pp. 385 390, 1967.

33）西村俊夫・張 東一・市千寿: プログラム応力下にお ける軟鋼材の 疲れ寿命, 東工大土木工学科研究報告, No. 17 , pp. $77 \sim 90,1974-12$.

34) Schijve, J. : Significance of fatigue cracks in microrange and macro-range, ASTM, STP, No. 415, 1967.

35) Klima, S.T. : Ultrasonic detection and measurement of fatigue cracks in notched specimens, Experimental Mechanics, May, 1969.

36）西原利夫・河本 実: 腐食法による疲れ部分の検出, 日 本機械学会論文集, Vol. 5, No. 20, 1939.

(1977.4.21 - 受付) 